\title{
EFFECTS OF WATER ON THE GLASS TRANSFORMATION TEMPERATURE OF RHYOLITIC ROCK MELT
}

\author{
Hiromitsu TANiguchi \\ Department of Earth Science, Science Education Institute of Osaka \\ Prefecture, Karitacho, Sumiyoshiku, Osaka, Japan
}

\begin{abstract}
The glass transformation temperature $\left(T_{g}\right)$ of rhyolitic rock melt was considerably influenced by the content of water in the melt. $T_{g}$ determined by means of the differential thermal analysis-thermogravimetric analysis under various experimental conditions ranged from $490^{\circ}$ to $760^{\circ} \mathrm{C}$, and decreased linearly with increasing water content in the melt at $T_{g}$. The experimental equation for the relation was $T_{g}=778-223 W_{\mathrm{H}_{2} \mathrm{O}}$. The decrease of $T_{g}$ with the increase of water may be explained by a decrease of the degree of polymerization of silicate anions in the rock melt as was analogized from the case of organic polymer solution.

In the experiments under the same conditions (sample grain size, heating rate), a strong correlation was observed between $T_{g}$ and water released between $T_{g}$ and $950^{\circ} \mathrm{C}$. On the other hand, it was difficult to find a certain relationship between $\stackrel{g}{T}_{g}$ and water released at above $950^{\circ} \mathrm{C}$. These results can be explained in terms of the difference of the force constant of $\mathrm{OH}$ bonding of water. The water which had a smaller force constant dissociated from the melt structure at lower temperature, moved freely among the melt structure and destroyed Si-O-Si bonds by the collision with the bonds. Thus the water had a direct effect upon $T_{\boldsymbol{g}}$.
\end{abstract}

\section{INTRODUCTION}

A basic study on the glass transformation temperature $\left(T_{g}\right)$ of the rock melt (the silicate melt having a composition corresponding to that of a igneous rock) is very important to understand the physical properties and the structure of a magma, and the genesis of a glassy rock.

Generally, a material which is changed into the "amorphous solid" state has two distinct characteristic temperatures. One is the melting temperature $\left(T_{m}\right)$ or liquidus temperature $\left(T_{1}\right)$, and the other is $T_{g} . T_{m}$ (or $\left.T_{1}\right)$ is a "first-order transition" temperature, whereas $T_{g}$ at which the material transforms from the super-cooled liquid state to the glassy state is considered to be a "second -order transition" temperature (Boyer and Spencer, 1944; Spencer and Boyer, 1946; Carmichael et al., 1974).

The glass transformation temperature is very important to gain a better understanding of not only the physical properties such as viscosity (Narayanswamy, 1971; Carmichael et al., 1974), heat capacity, thermal conductivity and melting temperature of a melt (Sakka and Mackenzie, 1971), but also the movements and the polymerization degree of the segments in the melt (Fox and Flory, 1950; Gordon, 1963).

Few reports on $T_{g}$ of a rock melt have been published to date. Shaw (1968) found an indication of $T_{g}$ for a rhyolitic obsidian at about $700^{\circ} \mathrm{C}$ by the change in the slope of 
the diffusion coefficient for water. Taniguchi (1974) reported that $T_{g}$ for a rhyolitic obsidian was about $670^{\circ} \mathrm{C}$ by means of the differential thermal analysis. Bacon (1977) reported that $T_{\mathrm{g}}$ for a rhyolitic glass determined on the basis of the mean specific heat measurement was about $790^{\circ} \mathrm{C}$. These three values are not consistent with each other. The different method used for the determination and the different water content in the sample might cause the discrepancy.

The purpose of this study is to determine $T_{g}$ of rhyolitic rock melts of various water contents and to consider the effect of water on the melt structure on the basis of the relationship between $T_{g}$ and the water content.

\section{SAMPLES}

The volcanic glasses separated from obisidians were used in the experiments. The chemical compositions of the volcanic glasses and the obsidians have been already reported by Kawano (1929) and Taniguchi (1974). The contents of $\mathrm{SiO}_{2}$ and water of the samples are shown in Table 1 . Though some values of $\mathrm{SiO}_{2}$ content in this table are

Table 1. The explanations of the samples used in the present experiments.

\begin{tabular}{|c|c|c|c|c|}
\hline $\begin{array}{c}\text { Sample } \\
\text { No. }\end{array}$ & Locality & $\begin{array}{l}\mathrm{SiO}_{2}{ }^{*} \\
(w t . \%)\end{array}$ & $\begin{array}{l}\mathrm{H}_{2} \mathrm{O}(+) \\
(w t . \%)\end{array}$ & Reference \\
\hline 1 & H1meshita & $76.2^{* *}$ & $0,36^{* * *}$ & Kawano $(1929)$ \\
\hline 2 & Shfratakt & $75.4^{\star \star}$ & $0.96^{* \star *}$ & Kawano (1929) \\
\hline 3 & Tokachi & 76.0 & 0.63 & Taniguchi(1974) \\
\hline 4 & Kawasaki & 76.1 & 1.12 & $\operatorname{Taniguch} 1(1974)$ \\
\hline 5 & Koshigatake & $75.3^{* *}$ & $0.79^{\star \star \star}$ & Kawano(1929) \\
\hline 6 & Kozushima & 76.4 & 0.39 & Tanfguchi $(1974)$ \\
\hline 7 & Wadatoge & $77.0^{\star \star}$ & $1.14^{* \hbar *}$ & Kawano(1929) \\
\hline
\end{tabular}

* The silica content on the anhydrous basis.

** The silica content of bulk rock (obsidian).

*** Water content determined in the present experiment. the bulk rock composition, they are regarded to be nearly equal to the $\mathrm{SiO}_{2}$ content of glass, since the total amount of crystals in those obsidians are less than 1 vol. \%. The $\mathrm{SiO}_{2}$ content ranges from 75.3 to $77.0 \mathrm{wt}$. $\%$ and the average is $76.1 \mathrm{wt} . \%$. These values indicate that the samples can be regarded as almost identical with each other in the accuracy required for the later discussions. Since the water contents are very important in the later discussion, those of some samples (sample nos. 1, 2, 5, 7) has been reanalysed in the present experiments.

\section{TGA-DTA ANALYSIS}

Thermogravimetric analysis (TGA) differential thermal analysis (DTA) curves were determined by means of a TGA-DTA system of Rigaku Denki (high temperature type) in air with $\alpha-\mathrm{Al}_{2} \mathrm{O}_{3}$ as standard material.

Figure 1 shows TGA-DTA curves of the sample of Kozu-shima as an example. Figure 2 is generalized TGA-DTA curves of rhyolitic rock melts. Generally, two types of losses in weight appeared on the TGA curve. The first weight loss appeared in a region of $100^{\circ}-300^{\circ} \mathrm{C}$, and the second in a region of $400^{\circ}-1100^{\circ} \mathrm{C}$. However, some samples gave the TGA curves that kept the weight constant at the temperature range between $900^{\circ} \mathrm{C}$ and $1000^{\circ} \mathrm{C}$.

All DTA curves showed an endothermic peak at a temperature between $450^{\circ} \mathrm{C}$ and $800^{\circ} \mathrm{C}$, and an exthothermic peak at about $1200^{\circ} \mathrm{C}$. Some DTA curves showed not only the two peaks mentioned above but a weak endothermic peak ranging from $100^{\circ}$ to $200^{\circ}$ $\mathrm{C}$, and the starting temperature of this peak agreed with that of the first weight loss on the TGA curve. Taniguchi (1972) demonstrated on the basis of the infra-red 


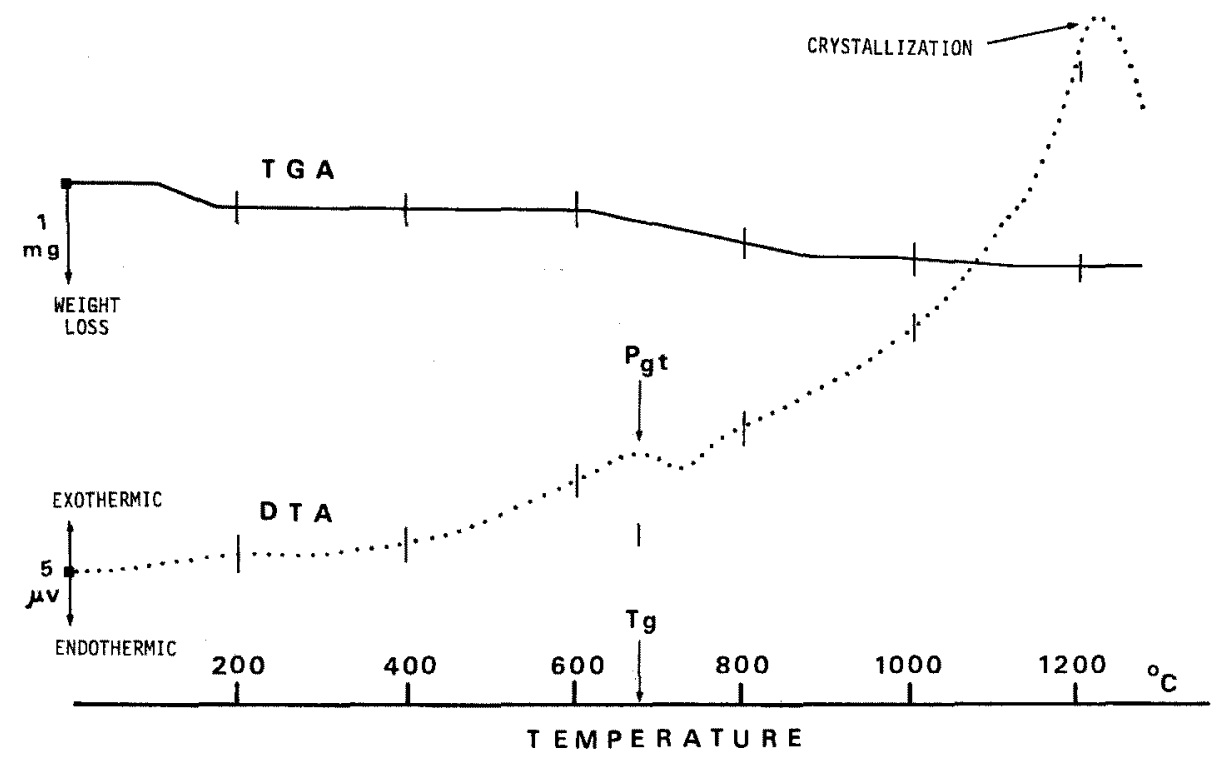

Fig. 1. Example of TGA-DTA curves of the rhyolitic rock melt from Kozushima. $P_{g t}=$ glass transformation point. $T_{g}=$ glass transformation temperature.

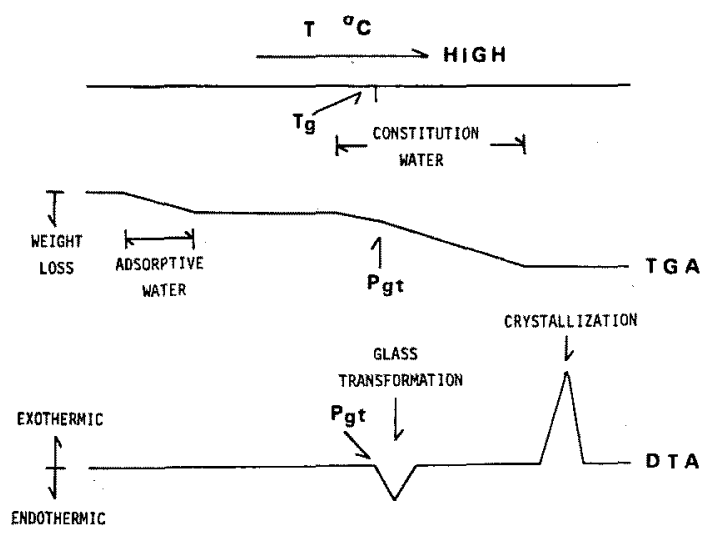

Fig. 2. Generalized figure showing TGA-DTA curves of rhyolitic rock melt.

spectral data that the amount of water in volcanic glasses decreased rapidly by heating at $120^{\circ} \mathrm{C}$. Consequently, the phenomena which were seen over a temperature range from $100^{\circ}$ to $300^{\circ} \mathrm{C}$ on TGA-DTA curves were due to the evaporation of adsorptive water in the sample. The exthothermic peak mentioned above was due to the nucleation of cristobalite.

Tool and Eichlin (1931), Kühne and Skatulla (1959) and Yamamoto et al. (1964) reported that the DTA curve of glass showed an endothermic peak due to the glass transformation. According to their studies, $T_{\mathrm{g}}$ is the starting temperature of the endothermic peak. In the present experiments, the endothermic peak appeared at temperature between $450^{\circ} \mathrm{C}$ and $800^{\circ} \mathrm{C}$ is not directly related to the weight loss. In the samples heated up to a temperature between the endothermic peak and the exthothermic peak the nucleation of crystal was not observed. The scanning electron microscopical observation $(\times 10,000)$ showed that the sample quenched from the temperature of $T_{g}+30^{\circ} \mathrm{C}$ had not any texture which indicated the vesiculation in the sample. By this fact, it was estimated that the peak was not concerned in the separation of vapour phase in the melt. These facts support the conclusion that the endothermic peak which appeared at temperature between $450^{\circ} \mathrm{C}$ and $800^{\circ} \mathrm{C}$ was due to the glass transformation.

The weight loss which began at above $400^{\circ} \mathrm{C}$ was due to the release of constitution 
Table 2. $T_{g}$ and the various water contents determined on the basis of the TGA-DTA curves.

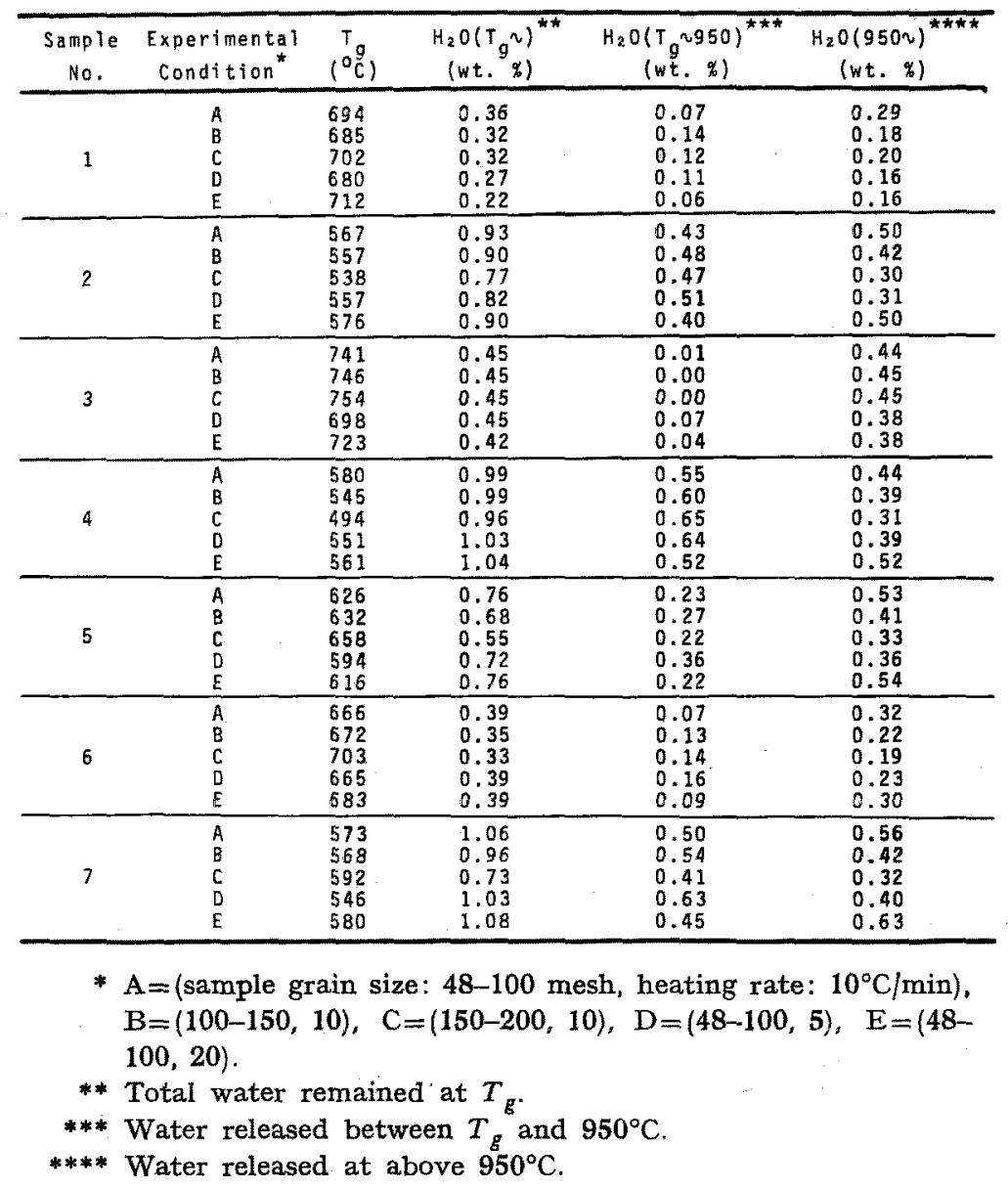

water judging from the infra-red spectral data by Taniguchi (1972).

In some samples the slopes of the weight losses became steeper at $T_{g}$. This fact may be interpreated as follows. The silicate anions in the rock melt begin to dissociate, rotate and translate at $T_{g}$ during heating, and concomitantly the structure of the melt begins to become loose. These effects promote the dissociation of the constitution water and its easy movement at above $T_{g}$. This behavior is in harmony with the idea that the effect of water below $T_{g}$ is not significant, but an increase in the thermal expansion with addition of water at above $T_{g}$ is pronounced (Maklad and
Kreidl, 1971).

The increase in weight by the oxidation of ferrous iron in the sample, which were used for the measurements of TGA-DTA curves, were estimated to be less than 0.05 wt. $\%$ on the basis of the results of chemical analysis. Since the increase was very small comparing with the weight loss on the TGA curve, the amount of weight loss on the TGA curve is fairly a good approximation of the amount of constitution water released. Then, we can calculate directly the amount of water released at an arbitrary temperature by use of the TGA curve.

The experimental results are sum- 
marized in Table 2. The amount of water remained in the sample at $T_{\mathrm{g}}$ was calculated from the chemical composition and the TGA curve.

\section{Discussion}

Effect of water on $T_{\boldsymbol{g}}$

Structural formulas of water in a glass, which were mainly identified in artificial simple glasses on the basis of infra-red spectral data (Scholze, 1959; Adams, 1961), are illustrated below.

(1) $\equiv \mathrm{Si}-\mathrm{OH} . \quad$ free $\mathrm{OH}$

(2) $\equiv \mathrm{Si}-\mathrm{OH} \ldots \mathrm{O}<$ hydrogen-bonded $\mathrm{OH}$ with bridging oxygen

(3) $\equiv \mathrm{Si}-\mathrm{OH} \cdots \mathrm{O}$ - hydrogen-bonded $\mathrm{OH}$ with non-bridging oxygen

Water contained in the volcanic glasses of obsidians are mainly free $\mathrm{OH}$ (Taniguchi, 1972). Several authors (Scholze, 1959; Walsh et al., 1956; Burnham and Davies, 1974) demonstrated that the water dissolved in the silicate melts was linearly proportional to the square root of the partial pressure of water, $\left(P_{\mathrm{H}_{\mathrm{O}} \mathrm{O}}\right)^{1 / 2}$. Their experimental results indicate the presence of the following reaction between a water molecule and a network structure of the rock melt,

$$
\begin{aligned}
& \equiv \mathrm{Si}-\mathrm{O}-\mathrm{Si} \equiv+\mathrm{H}_{2} \mathrm{O} \\
& \quad=\equiv \mathrm{Si}-\mathrm{OH}+\mathrm{HO}-\mathrm{Si} \equiv
\end{aligned}
$$

This reaction means that an oxo-bridge is destroyed by a water molecule, and the average degree of polymerization (DP) of silicate anions in the rock melt decreases with increase of water. The degree of polymerization of molecules in an organic polymer solution is inversely proportional to the number of the broken bonds (Gordon, 1963). When compared with this fact, it is assumed that DP of the silicate anions in the rock melt is also inversely proportional to the number of the broken Si-O-Si bonds.
The number of the broken bonds in the rock melt due to the addition of water is a function of the amount of water (Taniguchi, 1974). Then, the following relationship should be valid:

$$
D P=K \mid f\left(W_{\mathrm{H}_{\mathbf{2}} \mathrm{O}}\right)
$$

where $K$ is a constant, $f\left(W_{\mathrm{H}_{\mathrm{g}} \mathrm{O}}\right)$ is a monotone increasing function of $W_{\mathrm{H}, \mathrm{O}}$, the water content. On the other hand, the following relationship exists between the molecular weight and the glass transformation temperature of organic polymer (Haisa, 1967):

$$
T_{g}=T_{g \circ 0} \cdot\left(1-\varepsilon / M_{p}\right)
$$

where $T_{g \infty}$ and $\varepsilon$ are constants, and $M_{p}$ average molecular weight of polymer.

The relationship between the molecular weight and the degree of polymerization is as follows:

$$
M_{p}=D P \cdot M_{m}
$$

where $M_{m}$ is the molecular weight of monomer. We assume that the relationship (3) holds for the case of rock melt. Substituting the equations (2) and (4) into the equation (3), we obtain:

$$
\begin{aligned}
T_{g} & =T_{g \infty}\left\{1-\varepsilon /\left[K \cdot M_{m} / f\left(W_{\mathrm{H}_{\mathbf{2}} \mathrm{O}}\right)\right]\right\} \\
& =T_{g \infty}-K^{\prime} \cdot f\left(W_{\mathrm{H}_{\mathbf{2}} \mathrm{O}}\right)
\end{aligned}
$$

where $K^{\prime}=\varepsilon \cdot T_{g \infty} / K \cdot M_{m}$. Since $\varepsilon, T_{g \infty}, K$ and $M_{m}$ are positive values, $K^{\prime}$ is always positive. Then equation (5) indicates that the plot of $T_{g}$ against the water content gives a straight line or a smooth curve, along which $T_{\boldsymbol{g}}$ decreases with increase of water.

\section{Interpretation of experimental results}

Figure 3 shows the relationship between $T_{g}$ and the amount of water remained at $T_{g}$. Roughly speaking, $T_{g}$ decreases linearly with increase of the water content, in spite of the difference of the experimental condition. The experimental equation for the relation 


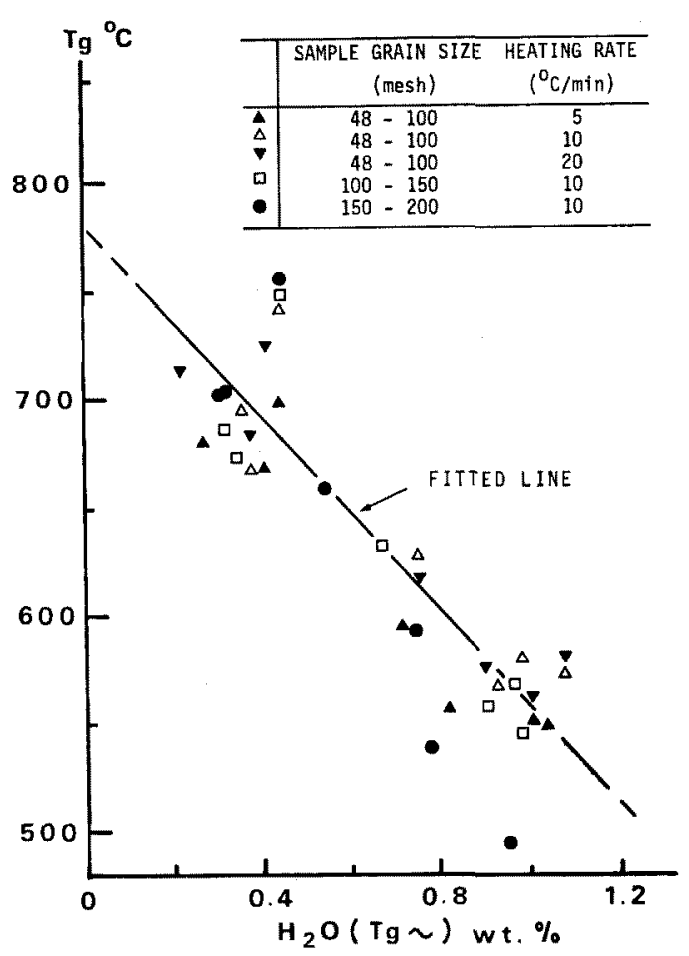

Fig. 3. The relationship between $T_{g}$ and the amount of water remained in the sample at $T_{g}$.

obtained by the least squares method is as follows:

$$
T_{\mathrm{g}}=778-223 W_{\mathrm{H}_{2} \mathrm{O}}
$$

The equation (6) is in harmony with equation (5). Comparing the equation (6) with (5), we can obtain the following equations.

$$
\begin{aligned}
& T_{g_{00}}=778^{\circ} \mathrm{C} \text { and } \\
& f\left(W_{\mathbf{H}_{\mathbf{2}} \mathrm{O}}\right)=\left(223 / K^{\prime}\right) \cdot W_{\mathbf{H}_{\mathbf{z}} \mathbf{O}} .
\end{aligned}
$$

The value $T_{g \infty}$, which is $T_{g}$ of anhydrous melt, is similar to that determined on the basis of the mean specific heat measurement $\left(790^{\circ} \mathrm{C}\right)$ for anhydrous rhyolitic glass by Bacon (1977). These results suggested that the two assumptions mentioned previously were valid, i.e., the average degree of polymerization of the silicate anions in the rock melt was inversely related to the amount of water and the equation (3) was held between the average molecular weight

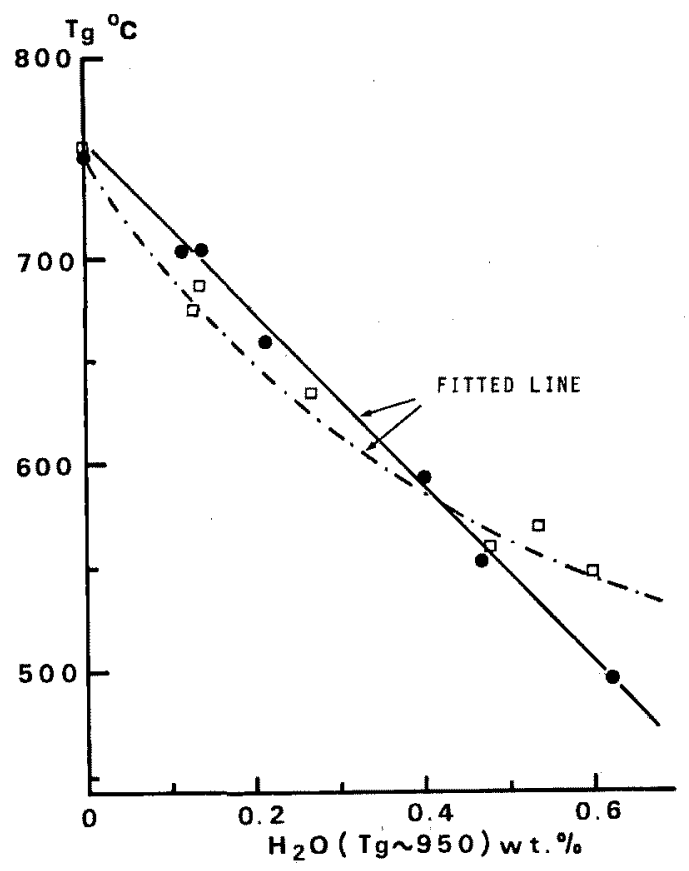

Fig. 4. The relationship between $T_{g}$ and the amount of water released between $T_{g}$ and $950^{\circ} \mathrm{C}$. Abbreviations are the same as in Fig. 3.

and $T_{g}$.

Generally, it is well known that volcanic glasses expand abruptly at about $950^{\circ}-1000^{\circ}$ $\mathrm{C}$ when being heated (Hirosue et al., 1972; Taniguchi, 1974). Figure 4 shows the relationship between $T_{g}$ and the amount of water released at a temperature range from $T_{g}$ to $950^{\circ} \mathrm{C}$. This water is considered to have the tendency to be released easily from the rock melt at lower temperatures. It is obvious from the comparison of Figs. 3 and 4 that a stronger correlation is observed between $T_{g}$ and the amount of water in Fig. 4 than in Fig. 3. The correlation determined under other experimental conditions was also excellent. Assuming that the correlation is a quadratic, the experimental equations calculated by the least squares method are shown in Table 3 . It is obvious that $T_{g}$ is affected by the experimental conditions although the quantity 
Table 3. Experimental equations for the relations between $T_{g}$ and the water released between $T_{g}$ and $950^{\circ} \mathrm{C}$.

\begin{tabular}{|c|c|c|}
\hline $\begin{array}{c}\text { Sample arain size } \\
\text { (mesh) }\end{array}$ & $\begin{array}{c}\text { Heating rate } \\
\left\{{ }^{\circ} \mathrm{C} / \mathrm{m}\{\mathrm{n}\}\right.\end{array}$ & Exoerimental eouation \\
\hline $48-100$ & 10 & $T_{\mathrm{g}}=908 \mathrm{H}_{\mathrm{H}_{2} \mathrm{O}}^{2}=795 \mathrm{~N}_{\mathrm{H}_{2} \mathrm{O}}+744$ \\
\hline $100-150$ & 10 & $T_{0}=391 \mathrm{~K}_{\mathrm{H}_{2} \mathrm{O}}^{2}-567 \mathrm{H}_{\mathrm{H}_{3} \mathrm{O}}+749$ \\
\hline $150-200$ & 10 & ${ }_{g}=31 \mathrm{H}_{\mathrm{H}_{2} \mathrm{O}}^{2}-443 \mathrm{H}_{\mathrm{H}_{2} \mathrm{O}}+758$ \\
\hline $48-100$ & 5 & $T_{9}=349 \mathrm{KH}_{\mathrm{H}_{2} \mathrm{O}}^{2}=524 \mathrm{H}_{\mathrm{H}_{2} \mathrm{O}}+73 \mathrm{~B}$ \\
\hline $48-100$ & 20 & ${ }_{g}=689 W_{\mathrm{H}_{2} \mathrm{O}}^{2}-693 \mathrm{H}_{\mathrm{H}_{2} \mathrm{O}}+742$ \\
\hline
\end{tabular}

of water in the sample is the same. On the other hand, it was difficult to find a definite relation between $T_{g}$ and the amount of water released at above $950^{\circ} \mathrm{C}$ (see Table 2). These experimental results indicate that water released between $T_{g}$ and $950^{\circ} \mathrm{C}$ has a stronger effect on $T_{g}$ than total water remained at $T_{g}$ or water released at above $950^{\circ} \mathrm{C}$.

Taniguchi (1972) demonstrated that the infra-red absorption peak in the region of $3450 \mathrm{~cm}^{-1}$ due to the presence of water shifted to the higher wave number with increasing temperature in heat treatments of the volcanic glass. Generally speaking, the relation between the wave number $(\nu)$ and the force constant $(f)$ of the stretching vibration of a diatomic molecule is formulated as follows:

$$
\nu=(1 / 2 \pi c) \cdot(f / \mu)^{1 / 2}
$$

where $c=$ light velocity and $\mu=$ reduced mass.

As is obvious from the equation, the wave number increases with an increase of the force constant. Consequently, water released at lower temperature had smaller force constant. The water might dissociate easily from the network at low temperature, moved through the network and then destroyed the Si-O-Si bonds by the collision with the bonds. These phenomena may have an effect on decreasing $T_{\boldsymbol{g}}$. On the other hand, since water released at above $950^{\circ} \mathrm{C}$ had a large force constant, the water could not dissociate at low temperature and could have only a small effect upon $T_{g}$.

\section{Summary AND Conclustons}

In the present experiments, the glass transformation temperature of rhyolitic rock melts has been studied in connection with water contents on the basis of the TGADTA, and we can draw the following conclusion.

(1) $T_{g}$ of the rhyolitic rock melt was influenced considerably by water in the melt.

(2) $T_{g}$ ranged from $490^{\circ}$ to $760^{\circ} \mathrm{C}$ in the present experiments, and decreased linearly with increase of water $(<1.1 \mathrm{wt} . \%)$ in the melt at $T_{g}$. The experimental equation for the relation is $T_{g}=778-223 W_{\mathrm{H}_{2} \mathrm{O}}$.

(3) The average degree of polymerization of silicate anions in the rock melt may be inversely proportional to the amount of water.

(4) The equation $T_{g}=T_{g \infty} \cdot\left(1-\varepsilon / M_{p}\right)$ may be useful to the relation between the average molecular weight of silicate anions in the rock melt and $T_{g}$.

(5) The stronger correlation was observed between $T_{g}$ and the water released between $T_{g}$ and $950^{\circ} \mathrm{C}$ than that between $T_{g}$ and total water remained at $T_{g}$ or water released at above $950^{\circ} \mathrm{C}$.

(6) Since the water released at lower temperatures $\left(T_{g} \sim 950^{\circ} \mathrm{C}\right)$ had the smaller force constant of $\mathrm{OH}$ bonding, it dissociated easily from the network structure at lower temperatures, destroying the Si-O-Si bonds.

\section{ACKNOWLEDGMENTS}

The author would like to express his appreciation to Professor Hitoshi Onuki of Hirosaki University, Professor Tsutomu Murase of Institute of Vocational Training 
and Professor Kenzo Yagi of Hokkaido University for their critical reading of the manuscript. The author also thanks Dr. Yoshiro Moriya of Government Industrial Research Institute, Dr. Isao Muori and Mr. Kiyoshige Ochiai of Science Education Insitute of Osaka Prefecture for their helpful suggestions. A part of samples were kindly provided by Assistant Professor Mutsumi Miyachi of Kyushu University.

\section{REFERENCES}

Adams, R.V. (1961) Infra-red absorption due to water in glasses. Phys. Chem. Glasses, 2, 3949.

Bacon, C.R. (1977) High temperature heat content and heat capacity of silicate galsses: Experimental determination and a model for calculation. Am. J.Sci., 277, 109-135.

Boyer, R.F. and Spencer, R.S. (1944) Thermal expansion and second-order transition effects in high polymers. Part I. Experimental results. J. Appl. Phys., 15, 398-405.

Burnham, C.W. and Davies, N.F. (1974) The role of $\mathrm{H}_{2} \mathrm{O}$ in silicate melts: II. Thermodynamic and phase relations in the system $\mathrm{NaAlS}_{2} \mathrm{O}_{8}$ $\mathrm{H}_{2} \mathrm{O}$ to 10 kilobars, $700^{\circ}$ to $1100^{\circ} \mathrm{C}$. Amer. $J$. Sci., 274, 902-940.

Carmichael, I.S.E., Turner, F.J. and Verhoogen, J. (1974) Igneous Petrology. McGraw-Hill, New Yovk, pp. 125-147.

Fox, T.G. Jr. and Flory, P.J. (1950) Second-order transition and related properties of polystyrene. I. Influence of molecular weight. J.Appl. Phys., 21, 581-591.

Gordon, M. (1963) High polymers-Structure and physical properties. Iliffe Books, pp. 59 (in Japanese translation).

Haisa, M. (1967) Polymer. Kagakudojin, pp. 223 (in Japanese).

Hirosue, H., Matsuda, O., Koga, Y. and Hashizume, $Y$. (1972) Studies on the production of "Shirasu perlite". Rep. Govern. Indust. Res.
Inst. Kyushu, 7, 390-396 (in Japanese with English abstract).

Kawano, Y. (1929) Natural glasses in Japan. Geol. Surv. Rep., 134, 1-29 (in Japanese with English abstract).

Kühne, K. and Skatulla, W. (1959) Physikalische und Chemische Untershchungen an Gläser vom Vycor-Typ. Silikattechnik, 10, 105-118.

Maklad, M.S, and Kreidl, N.J. (1971) Some effects of $\mathrm{OH}$ groups on sodium silicate glasses. Proc. IX International congress on glass, 75-100.

Narayanaswamy, O.S. (1971) A model of structural relaxation in glass. $J$. Am. Ceram. Soc., 54, 491-498.

Sakka, S. and Mackenzie, J.D. (1971) Relation between apparent glass transition temperature and liquidus temperature for inorganic glasses. J. Non-Crystalline Solids, 6, 145-162.

Scholze, H. (1959) Der Einbau des Wassers in Gläsern. Glastechn. Ber., 32, 142-152.

Shaw, H.R. (1968) Chemical states of $\mathrm{H}_{2} \mathrm{O}$ and reaction in silicate- $\mathrm{H}_{2} \mathrm{O}$ liquids and glasses. Ann. Mtg. Geol. Soc. Am., 274-275.

Spencer, R.S. and Boyer, R.F. (1946) Thermal expansion and second-order transition effects in high polymers. III. Time effects. $J$. $A p p l$. Phys., 17, 398-404.

Taniguchi, $\mathrm{H}$. (1972) Studies on $\mathrm{Si}^{\mathrm{a}+}$ ion, $\mathrm{Al}^{\mathrm{a}+}$ ion and $\mathrm{H}_{2} \mathrm{O}(+)$ in volcanic glasses by means of infra-red absorption and other methods. $J$. Japan Assoc. Min. Petv. Econ. Geol., 67, 291300 (in Japanese with English abstract).

Taniguchi, H. (1974) The study of the physical and chemical properties of some volcanic acid glasses. Sci. Rep. Tohoku Univ., III, XII, 189-237.

Tool, A.Q. and Eichlin, C.G. (1931) Variations caused in heating curves of glass by heat treatment. Bur. Stands., 6, 523-551.

Walsh, J.H., King, T.B. and Grant, N.J. (1956) Hydrogen in steel making slags. $J$. Metals, 8 , 1568-1576.

Yamamoto, A., Yamate, T. and Kunugi, M. (1964) Differential thermal analysis of glasses. Zairyo, 13, 880-884 (in Japanese with English abstract). 


\section{流䋌岩質岩石溶融体のガラス転移温度に及ばす水の影留}

谷口宏 充

流紋岩質火山ガラスを試料にして 熱分析 (TGA-DTA) を行い，ガラス転移温度（Tg）を決定した。全ての DTA 曲線は $490^{\circ} \sim 760^{\circ} \mathrm{C}$ の範囲内にガラス転移による吸熱ピークを示した。 Tgは Tgにおいて試料内に残留 する水の量に逆比例する。この事は水によってメルト内の珪酸陰イオンの平均重合度肪減少する事を意味してい る。又， $\mathrm{Tg}$ と $\mathrm{Tg} \sim 950^{\circ} \mathrm{C}$ の間に系外に放出される水の量との相関は， $\mathrm{Tg}$ 以上ない儿 $950^{\circ} \mathrm{C}$ 以上で放出さ机る ちのに較べ極めて良い。ての事はメルト構造におりる水の力の定数の違いによって説明される。すなわち定数の 小さな水はより低温においてメルト構造から解離し，熱運動を行いつ〉系外に向って拡散し酸素橋を破壞する。 その為に Tg は低下する。 